\title{
Genetic variations in the digestibility in sheep of selected whole-crop cereals used as silages
}

\author{
J. C. Emile ${ }^{1 \dagger}$, C. C. Jobim² ${ }^{2}$ F. Surault ${ }^{3}$ and Y. Barrière ${ }^{3}$ \\ ${ }^{1}$ Institut National de la Recherche Agronomique, Unité Expérimentale Fourrages et Environnement, 86600 Lusignan, France; ${ }^{2}$ Universidade Estadual de Maringa, \\ Maringa, Parana, Brazil; ${ }^{3}$ Institut National de la Recherche Agronomique, Unité de Génétique et d'Amélioration des Plantes Fourragères, 86600 Lusignan, France
}

(Received 22 September 2005; Accepted 6 April 2007)

Whole-plant winter cereals could be of great interest if used as silages for ruminant feeding as opposed to summer crops in that they would spare water resources or valorize low-input management. This study aimed to compare the feeding value of rye, barley, wheat (two genotypes) and triticale (six genotypes). The cereals were sown in October and harvested as silage in June. Forages were offered to Texel castrated sheep in order to evaluate the organic matter digestibility (OMd). The OMd of the wheat cultivars was higher $(61.6 \%, \mathrm{P}<0.05)$ than those of barley $(57.2 \%)$ and rye $(54.7 \%)$ but no different from that of triticale (60.6\%). Within the triticale genotypes, OMd ranged from 54.7 to $62.3 \%$. The presence of rough barbs should explain the relatively low intake of the cereals with the exception of wheat. Winter cereals provide good-quality forage for feeding ruminants. Wheat has a higher nutritional value than barley and rye and a wide variability for digestibility seems to exist within the triticale cultivars. Such variability in a species known for its ability to be cropped under limiting conditions should be explored in much greater depth as it could result in providing farmers with genotypes of good quality with an acceptable yield at a lower cost.

Keywords: digestibility, silage, triticale, wheat, whole-crop cereals

\section{Introduction}

Cereals are important contributors to ruminant feeding worldwide. They are most often used as grain, either in concentrate or as rough diet. However, cereals are often managed as forages, the whole plant being grazed, ensiled or green chopped. Whole-plant triticale seems to be a good forage alternative to traditional winter species such as barley and wheat. Its hardiness and high-yield potential under limiting conditions has been noticed in different areas of the world (Lozano et al., 1998; McLeod et al., 1998; Delogu et al. 2002). Its dual purpose, as a grain harvest occurring after the forage harvest, has also been pointed out (Andrews et al., 1991; Royo and Pares, 1996; Jobim and Emile, 1999).

This crop nowadays covers more than 330000 ha in France and up to 1200000 ha in the European Union (2005 data), but only a small part (from 5 to $10 \%$ depending to the areas) is used as forage. This culture could be of great interest compared with summer crops such as maize or sorghum silage in order to spare water resources or to

${ }^{\dagger}$ Email: jean-claude.emile@lusignan.inra.fr valorize low-input management (Bernard et al., 1992; Le Gall et al., 1998).

Feeding experiments with triticale silages are, however, infrequent and have given contrasting results (Zobell et al., 1992; McCartney and Vaage, 1994; Scerra et al., 1994), which may have prevented the development of this species as forage. On the other hand, a large variability is potentially available within this breeding species. Therefore, the objectives of this study were to evaluate the in vivo digestibility of selected whole-crop cereals in order to (i) evaluate and compare the quality of barley, wheat, rye and triticale and (ii) determine whether there are any differences among the triticale cultivars.

\section{Material and methods}

Plants and forage

Ten genotypes of winter cereals were sown in late October of 1997 at INRA Lusignan (France). Those genotypes included six cultivars of triticale ( $X$ Triticosecale Wittm.) 'Aubrac', 'Calao', 'Carnac', 'Inradi34-2', 'Lasko' and 'Trimaran'; two cultivars of wheat (Triticum aestivum L.) 'Renan' and 'Trémie'; one cultivar of barley (Hordeum vulgare L.) 
'Angela'; and one cultivar of rye (Secale cereale L.) 'Clou'. Plots were $1500 \mathrm{~m}^{2}$ for each genotype. The cereals were harvested as silage in the middle of June 1998 at the late milk-early dough grain stage in order to obtain a dry matter (DM) content of the silages approaching 30 to $35 \%$. Two experimental silos of approximately $450 \mathrm{~kg}$ DM were made for each genotype (Traineau, 1991) and stored outdoors 48 to 70 days prior to in vivo evaluation.

Grain content of the ensiled forage was estimated at the time of harvest from four samples of $0.25 \mathrm{~m}^{2}\left(0.5 \times 0.5 \mathrm{~m}^{2}\right)$ for each genotype. Throughout the in vivo evaluation, silage samples were taken twice a week, dried at $60^{\circ} \mathrm{C}$, bulked and ground through a 2-mm hammer mill for in situ evaluation. Other samples of offered silage were pressed. The resulting juice was frozen and then analysed in order to determine $\mathrm{pH}$, lactic acid, butyric acid, acetic acid, ammonianitrogen and soluble nitrogen $(\mathrm{N})$ according to standard methods.

In vivo digestibility evaluation

Twenty-four castrated Texel sheep housed individually in digestibility cages were allocated in four balanced groups of six sheep according to their weight (average weight of $83.0 \pm 1.5 \mathrm{~kg})$ and age. Each of the 20 silages (10 treatments $\times 2$ replications) was fed twice a day to one of those groups for 2 weeks. The measurement period lasted 5 days, after a 7-day-long period of adaptation. Feeding was adjusted to the maintenance requirement of each animal according to its metabolic weight $\left(40 \mathrm{~g} / \mathrm{kg}^{0.75}\right)$. Offered forage and faeces DM content were recorded daily. The ash, crude protein (CP), crude fibre (CF), fibre content (NDF, ADF, $A D L)$ and enzymatic digestibility (IVDMD) were assessed from a weekly bulk sample. The fibre content procedure was adapted from Goering and Van Soest (1970). Voluntary intake (VI), organic matter digestibility (OMd) and cell wall digestibility (NDFd), computed from offered forage, refusal and faeces content, were derived from the average value for 5 days and six sheep (Demarquilly et al., 1995). The net energy value for lactation in dairy cattle was computed according to Andrieu and Demarquilly (1987) and expressed as UFL (1 UFL $=7.106 \mathrm{MJ} / \mathrm{kg} \mathrm{DM}$ ). The non-digestible cell wall (NDFnd) was calculated according to Demarquilly et al. (1995) as $100 \times$ NDFnd $=$ NDF $\times(100-N D F d)$. Main and nested effects were tested by analysis of variance following the model: genotype + genotype(animal) and using the GLM procedure (Statistical Analysis Systems Institute (SAS), 1989). Genotype least-square means were compared by a Duncan test. The Pearson correlation coefficients between feeding value traits were performed using the CORR procedure (SAS, 1989).

\section{Results}

\section{Silage composition}

The chemical composition of the silages is given in Table 1. Silages DM content varied from 29.6 to $39.0 \%$ (34.2\% on average). Grain content at harvest time rose from 25 to $37 \%$ of the total DM. The average values for organic matter $(O M), C P, C F, N D F$ and lignin were respectively of 942,73 , 307,578 and $87 \mathrm{~g} / \mathrm{kg}$ DM. IVDMD fluctuated between 41.1 (rye) and $55.5 \%$ (barley), the triticale being intermediate from 45.0 to $51.8 \%$ according to the genotype.

The mean values for the silages conservation parameters, pH (4.26), ammonia- $\mathrm{N}(97 \mathrm{~g} / \mathrm{kg}$ total $\mathrm{N})$ and lactic acid ( $72 \%$ of the total acids) showed good silage fermentation (Table 2). Nevertheless, the amount of acetic acid (26\%) and butyric acid (2\%), and the amount of soluble N $(674 \mathrm{~g} /$ $\mathrm{kg}$ total $\mathrm{N} \%$ ) were higher than expected. The triticale Tremie had a high proportion of acetic acid (43\%).

\section{In vivo digestibility evaluation}

Despite the sheep being fed a limited amount, a high proportion of forage refusal was observed, from 3.8 to $20.4 \%$ of the total offered DM (Table 3). In order to prevent interactions between intake level and digestibility data, the option was made to discard individual digestibility data when the intake was lower than $30 \mathrm{~g} / \mathrm{kg}^{0.75}$. Observed OMd

Table 1 Chemical composition (dry matter (DM), organic matter (OM), crude protein (CP), crude fibre (CF), neutral-detergent fibre (NDF)) of the silages

\begin{tabular}{|c|c|c|c|c|c|c|c|}
\hline Genotype $^{\dagger}$ & DM $(\%)$ & Grain (\%) & OM (g/kg DM) & $C P(g / k g ~ D M)$ & CF (g/kg DM) & NDF (g/kg DM) & Lignin ( $g / k g ~ D M)$ \\
\hline B Angela & 38.6 & 37 & 947 & 74 & 274 & 513 & 81 \\
\hline R Clou & 31.9 & 25 & 931 & 67 & 343 & 615 & 108 \\
\hline W Trémie & 33.5 & 32 & 942 & 81 & 278 & 532 & 73 \\
\hline W Renan & 34.7 & 26 & 943 & 82 & 285 & 556 & 91 \\
\hline T Aubrac & 29.6 & 28 & 933 & 72 & 326 & 598 & 98 \\
\hline T Calao & 34.0 & 27 & 944 & 71 & 324 & 603 & 84 \\
\hline T Carnac & 32.3 & 28 & 941 & 73 & 304 & 564 & 83 \\
\hline T Inradi34 & 32.9 & 27 & 942 & 72 & 325 & 629 & 88 \\
\hline T Lasko & 35.7 & 26 & 945 & 72 & 327 & 617 & 83 \\
\hline T Trimaran & 39.0 & 31 & 951 & 68 & 283 & 558 & 84 \\
\hline
\end{tabular}

${ }^{+}$Abbreviation for silage species: $\mathrm{B}=$ barley; $\mathrm{R}=$ rye; $\mathrm{W}=$ wheat; $\mathrm{T}=$ triticale. 
Emile, Jobim, Surault and Barrière

Table 2 Fermentative characterization of the silages

\begin{tabular}{|c|c|c|c|c|c|c|}
\hline Genotype $^{\dagger}$ & $\mathrm{pH}$ & Lactic acid (g/kg DM) & Acetic acid (g/kg DM) & Butyric acid (g/kg DM) & $\mathrm{NH}_{3}-\mathrm{N}(\mathrm{g} / \mathrm{kg} \mathrm{N})$ & $\mathrm{N}$-soluble $(\mathrm{g} / \mathrm{kg} \mathrm{N})$ \\
\hline B Angela & 4.69 & 23.4 & 8.6 & 1.0 & 92 & 513 \\
\hline R Clou & 4.43 & 34.3 & 8.8 & 1.3 & 124 & 773 \\
\hline W Trémie & 3.91 & 38.3 & 29.8 & 0.9 & 99 & 669 \\
\hline W Renan & 4.24 & 24.1 & 12.0 & 1.1 & 101 & 650 \\
\hline T Aubrac & 4.31 & 50.7 & 14.8 & 1.3 & 94 & 666 \\
\hline T Calao & 4.13 & 44.2 & 10.3 & 1.4 & 89 & 680 \\
\hline T Carnac & 4.15 & 41.6 & 12.9 & 1.4 & 102 & 696 \\
\hline T Inradi34 & 4.33 & 40.3 & 11.5 & 1.0 & 93 & 732 \\
\hline T Lasko & 4.29 & 31.4 & 9.6 & 1.0 & 87 & 693 \\
\hline T Trimaran & 4.15 & 30.3 & 10.1 & 0.5 & 87 & 672 \\
\hline
\end{tabular}

${ }^{+}$Abbreviation for silage species: $B=$ barley; $R=$ rye; $W=$ wheat; $T=$ triticale.

Table 3 Refusal forage, enzymatic digestibility (IVDMD), organic matter digestibility (OMd), neutral-detergent fibre digestibility (NDFd), non-digestible NDF (NDFnd) and net energy content (UFL)

\begin{tabular}{lcccccc}
\hline \hline Genotype $^{\dagger}$ & Refusal (\%) & IVDMD (\%) & OMd (\%) & NDFd (\%) & NDFnd (\%) $^{\ddagger}$ & UFL $^{\S}$ \\
\hline B Angela & $14.1^{\mathrm{ab}}$ & 55.7 & $57.2^{\mathrm{bc}}$ & $38.2^{\mathrm{e}}$ & 31.7 & $0.66^{\mathrm{b}}$ \\
R Clou & $15.8^{\mathrm{a}}$ & 41.1 & $54.7^{\mathrm{c}}$ & $45.6^{\mathrm{cd}}$ & 33.4 & $0.61^{\mathrm{c}}$ \\
W Trémie & $3.8^{\mathrm{b}}$ & 54.0 & $60.8^{\mathrm{a}}$ & $47.6^{\mathrm{c}}$ & 27.9 & $0.71^{\mathrm{ab}}$ \\
W Renan & $4.3^{\mathrm{b}}$ & 51.9 & $62.4^{\mathrm{a}}$ & $51.4^{\mathrm{b}}$ & 27.0 & $0.73^{\mathrm{a}}$ \\
T Aubrac & $14.0^{\mathrm{ab}}$ & 48.3 & $54.7^{\mathrm{c}}$ & $44.4^{\mathrm{d}}$ & 33.3 & $0.61^{\mathrm{c}}$ \\
T Calao & $20.4^{\mathrm{a}}$ & 46.2 & $60.9^{\mathrm{a}}$ & $52.0^{\mathrm{b}}$ & 29.0 & $0.72^{\mathrm{ab}}$ \\
T Carnac & $16.9^{\mathrm{a}}$ & 50.3 & $62.3^{\mathrm{a}}$ & $50.6^{\mathrm{b}}$ & 27.7 & $0.73^{\mathrm{a}}$ \\
T Inradi34 & $13.6^{\mathrm{ab}}$ & 45.4 & $61.1^{\mathrm{a}}$ & $55.1^{\mathrm{a}}$ & 28.2 & $0.71^{\mathrm{ab}}$ \\
T Lasko & $20.0^{\mathrm{a}}$ & 45.0 & $59.5^{\mathrm{ab}}$ & $52.4^{\mathrm{b}}$ & 30.2 & $0.69^{\mathrm{ab}}$ \\
T Trimaran & $19.3^{\mathrm{a}}$ & 51.8 & $59.2^{\mathrm{ab}}$ & $44.4^{\mathrm{d}}$ & 30.8 & $0.69^{\mathrm{ab}}$ \\
\hline \hline
\end{tabular}

$\mathrm{a}, \mathrm{b}, \mathrm{c}, \mathrm{d}, \mathrm{e}$ Values within columns with different superscripts are different $(P<0.01)$.

${ }^{+}$Abbreviation for silage species: $B=$ barley; $R=$ rye; $W=$ wheat; $T=$ triticale.

$\neq 100 \times$ NDFnd $=$ NDF $\times(100-$ CWD $)$.

§ UFL: milk net energy content computed with OMd, intake, crude protein and crude fibre (Weende) $(1 \mathrm{UFL}=7.106 \mathrm{MJ})$.

ranged from less than $55 \%$ to more than $62 \%$. Wheat cultivars $(61.6 \%$, mean value) appeared more digestible than the barley $(57.2 \%)$ and the rye $(54.7 \%)$ but no different from the triticales (mean value, $60.6 \%$ ). Within triticale genotypes, OMd ranged from 54.7 to $62.3 \%$, differences are significant.

The NDFd varied between 38.2 (barley) and $55.1 \%$ (triticale inra di34-2) taking into account all genotypes, and between 44.4 and $55.1 \%$ within triticales. Concerning the wheat cultivars, Renan was more digestible than Trémie. NDFnd varied from 27.0 to $33.4 \%$.

The mean feeding value of triticale was $0.69 \mathrm{UFL}$ $(=4.90 \mathrm{MJ})$, varying from 0.61 to $0.73 \mathrm{UFL}$ depending on the cultivars, when wheat, barley and rye values were 0.72 , 0.66 and $0.61 \mathrm{UFL}$, respectively.

\section{Discussion}

The $\mathrm{pH}$ of silages was lower than 4.5, reflecting an active fermentation. There were no marked differences in ammonia- $\mathrm{N}$ and soluble $\mathrm{N}$ between genotypes and cultivars. The amount of acetic acid, butyric acid and the high level of soluble $\mathrm{N}$ can be attributed to the slower acidification of the forages in experimental silos than in larger ones. However, conservation characteristics were similar to those recorded in similar studies (Bergen et al., 1991; Scerra et al., 1994, Jobim et al., 1996) and appeared to be intermediate between those currently given for maize silage and for grass silage.

Despite the fact that forages were given in limited amounts, a low level of consumption was noticed. The refusals represent less than $5 \%$ for wheat cultivars but 14 to $20 \%$ for the triticales. As previously stated, the effect of the forage conservation on intake should probably be discarded. One could accuse the depressive effect of a high DM content, as often observed by farmers, but the DM contents were lower than the $40 \%$ critical value (29.6 to $39.0 \%$ ). Moreover, the presence of rough barbs on the spikes of the awned plants, which could physically decrease the palatability of the forages, must be considered. The wheat cultivars are barbless (Renan) or their barbs are smooth and short (Trémie). In a study involving sheep and growing heifers, McCartney and Vaage (1994) noticed palatability problems with the triticale diet and concluded it was related to its coarse texture. In their study, Scerra et al. (1994) attributed the poor palatability of triticale to the presence of barbs. 
Table 4 Correlations between feeding value traits: organic matter digestibility (OMd), neutral-detergent fibre (NDF), NDF digestibility (NDFd), non-digestible NDF (NDFnd) and enzymatic digestibility (IVDMD)

\begin{tabular}{lcccc}
\hline \hline & OMd & NDFd & NDF & NDFnd \\
\hline NDFd & $0.71^{* *}$ & - & - & - \\
NDF & -0.11 & $-0.58^{* *}$ & - & - \\
NDFnd & $-0.98^{* *}$ & $-0.72^{* *}$ & 0.13 & - \\
IVDMD & 0.22 & -0.45 & $-0.92 * *$ & -0.23 \\
\hline \hline
\end{tabular}

**P<0.01.

As noticed by Adesogan et al. (1998b) in an evaluation involving 36 winter wheat forages, the chemical composition data of the forages were inaccurate predictors of OMd. Variations in OM digestibilities were nevertheless linked to the NDF digestibility and strongly to the non-digestible NDF content (Table 4). Enzymatic digestibility (IVDMD) appeared closely dependent on the NDF content but not on the OM or the NDF digestibilities. As the enzymatic technique simulates the ruminal digestion, it does not sufficiently account for post-ruminal digestion of the cell wall and starch components of the plants.

The OMd values of the wheat and barley genotypes were consistent with the data given by Andrieu et al. (1988), Garnsworthy and Stokes (1993) and Adesogan et al. (1998a), but five points lower than data given by McCartney and Vaage (1994). Rye OMd was the lowest in this study and no comparative data seem to be available on this species. Those data need to be made relative because the potential genetic variations within those species were not been explored in this study. Triticale OMd values were similar to those of barley and wheat in this experiment and lower than in evaluations conducted by Scerra et al. (1994) and McCartney and Vaage (1994). The range of variation within this species (more than six points) was as wide as reported by Delogu et al. (2002) in an evaluation involving nine genotypes. This genetic variability for digestibility is well known in numerous forage species and is related to the amount of starch in the plant and also to the characteristics of the cell wall components of the genotypes.

\section{Conclusion}

Whole-crops winter cereals harvested as silage at 30 to $35 \%$ DM content provide forage of good quality for feeding ruminants. Among the species, wheat has a higher nutritional value than barley and rye. Within the six triticale genotypes, a variability for digestibility seems to exist. The best of them are better than the wheat cultivars while the worst are no different from that of rye. This fact is not surprising due to the genetic background of this species, but it is of importance for further development of the species. Such a variability in a species known for its ability to be cropped under limiting conditions (soil, manure, pest control) must be explored in greater depth. This could lead to providing farmers with genotypes of good quality with an acceptable yield under extensive conditions and at a lower cost.

\section{References}

Adesogan AT, Owen E and Givens DI 1998a. The chemical composition, digestibility and energy value of fermented and urea-treated whole crop wheat harvested at three stages of maturity. Grass and Forage Science 53, 66-75.

Adesogan AT, Owen E and Givens DI 1998b. Prediction of the in vivo digestibility of whole crop wheat from in vitro digestibility, chemical composition, in situ rumen degradability, in vitro gas production and near infrared reflectance spectroscopy. Animal Feed Science and Technology 74 259-272.

Andrieu J and Demarquilly C 1987. Valeur nutritive des fourrages: tables et prévision. Bulletin Technique CRZV de Theix, INRA 70, 61-73.

Andrieu J, Demarquilly C and Sauvant D 1988. Tables de la valeur alimentaire des aliments. In: Alimentation des bovins, ovins et caprins (ed. R Jarrige), pp. 356-444. INRA, Paris, France.

Andrews AC, Wright R, Simpson PG, Jessop R, Reeves S and Wheeler A 1991. Evaluation of new cultivars of triticale as dual-purpose forage and grain crops. Australian Journal of Experimental Agriculture 31, 769-775.

Bergen WG, Byrem TM and Grant AL 1991. Ensiling characteristics of wholecrop small grains harvested at milk and dough stages. Journal of Animal Science 69, 1766-1774.

Bernard M, Jestin L, Bernard S, Gay G and Bonhomme H 1992. Le triticale en France. Comptes Rendus de I'Académie d'Agriculture de France 78, 23-36.

Delogu G, Faccini N, Faccioli P, Reggiani F, Lendini M and Berardo N, Odoardi 2002. Dry matter yield and quality evaluation at two phenological stages of forage triticale grown in the Po Valley and Sardinia, Italy. Field Crops Research 74, 207-215.

Demarquilly C, Chenost M and Giger S 1995. Pertes fécales et digestibilités des aliments et des rations. In Nutrition des ruminants domestiques (ed. R Jarrige), pp. 601-647. INRA, Paris, France.

Garnsworthy PC and Stokes DT 1993. The nutritive value of wheat and oat silages ensiled on three cutting dates. Journal of Agricultural Science 121, 233-240.

Goering HK and Van Soest PJ 1970. Forage fiber analyses. Apparatus, reagents, procedures, and some applications. Agricultural handbook no. 379. US Department of Agriculture, Washington, DC.

Jobim CC, Reis RA and Rosa B 1996. Avaliaçao do triticale (X Triticosecale Wittm.) para silagem. Revista da Sociedade Brasileira de Zootecnia 25, 404-413.

Jobim CC and Emile JC 1999. Systèmes d'utilisation des céréales d'hiver pour I'alimentation des animaux au Brésil. Fourrages 159, 259-267.

Le Gall A, Delattre JC and Cabon G 1998. Les céréales immatures et la paille: une assurance pour les systèmes fourragers. Fourrages 156, 557-572.

Lozano AJ, Zamora VM, Solis HD, Mergoum M and Pfeiffer WH 1998. Triticale forage production and nutritional value in the northern region of Mexico. Proceedings of the fourth international triticale symposium (ed. P Juskin), pp. 259-263. Red Deer, Canada.

McCartney DH and Vaage AS 1994. Comparative yield and feeding value of barley, oat and triticale silages. Canadian Journal of Animal Science 74, 91-96. McLeod JG, Gan YT, Salmon DF and Baron VS 1998. Triticale biomass potential and quality on the Canadian praires. In: Proceedings of the fourth international triticale symposium (ed. P Juskin), pp. 264-267. Red Deer, Canada.

Royo C and Pares D 1996. Yield and quality of winter and spring triticales for forage and grain. Grass and Forage Science 51, 449-455.

Scerra V, Galvano F, Angelis Ade, Galvano M and Rapisarda A 1994. Research on nutritive value of Sicilian fodders and by-products. 6 . In vivo digestibility and estimation of the energy value of triticale silage. World Review of Animal Production 29, 66-71.

Statistical Analysis Systems Institute 1989. SAS/STAT ${ }^{\odot}$ user's guide (version 6.04). SAS Institute Inc., Cary, NC.

Traineau R 1991. Mise au point d'un matériel de récolte et de confections de silos adapté à des parcelles expérimentales. Fourrages 128, 465-473.

Zobell DR, Goonewardene LA and Engstrom DF 1992. Use of triticale silage in diets for growing steers. Canadian Journal of Animal Science 72, 181-184. 